\title{
Production of a cheese model for sensory evaluation of flavour compounds
}

\author{
C Salles 1, S Dalmas 1, C Septier 1, S Issanchou 1, \\ Y Noël ${ }^{2}$, P Etiévant ${ }^{1}$, JL Le Quéré ${ }^{1}$ \\ ${ }^{1}$ Laboratoire de recherches sur les arômes, INRA, 21034 Dijon cedex; \\ 2 Station de recherches en technologie et analyses laitières, INRA, 39801 Poligny cedex, France
}

(Received 19 April 1995; accepted 31 July 1995)

\begin{abstract}
Summary - A cheese model used to perform sensory evaluation of flavour compounds extracted from various cheese varieties was made with caseins, low heat milk powder, deodorized milk fat, $\mathrm{NaCl}$ and rennet. Its composition and physicochemical properties were close to mature hard cheese, apart from a lower dry matter content and sodium concentration, and a higher lactose concentration. Its preparation was established in order to avoid drainage for at least $24 \mathrm{~h}$, which should allow the incorporation of not only some lipophilic substances such as aromas but also some water-soluble substances such as amino acids and peptides. The rheological behaviour of the cheese model measured by a compression test had a pattern similar to some hard cheeses but with much lower values and its flavour was evaluated as neutral. Compared to some lightly flavoured cheeses, this cheese model was found to be slightly salty, bitter or sour, and had only a light milky aroma.
\end{abstract}

cheese model / composition / rheology / sensory evaluation

Résumé - Production d'un modèle fromage pour des évaluations sensorielles de composés aromatiques. Un modèle fromager permettant de réaliser des évaluations sensorielles de composés aromatiques isolés à partir de diverses variétés de fromages a été fabriqué avec de la caséine, de la poudre de lait faiblement chauffé, de la matière grasse laitière désodorisée, du chlorure de sodium et de la présure. Sa composition et ses propriétés physicochimiques étaient semblables à celles d'un fromage âgé, mis à part les taux plus faibles de matière sèche et de sodium, et une concentration en lactose plus importante. Sa préparation a été établie dans le but d'éviter un égouttage pendant au moins $24 \mathrm{~h}$, ce qui a permis l'incorporation non seulement de substances lipophiles comme des arômes mais aussi de composés hydrosolubles tels que des acides aminés et des peptides. Le comportement rhéologique du fromage modèle, mesuré par un test de compression, a un profil similaire à celui de fromages à pâte dure et sa flaveur a été évaluée comme étant neutre. Par comparaison avec des fromages ayant peu de flaveur, ce modèle fromage a été décrit comme légèrement salé, amer ou acide, et avait seulement un léger arôme de lait.

fromage modèle / composition / rhéologie / évaluation sensorielle 


\section{INTRODUCTION}

The flavour of cheeses has been studied extensively during the last 20 years and a great number of volatile compounds have been identified (Adda and Dumont, 1974; Groux and Moinas, 1974; Dumont et al, 1974; Cuer et al, 1979; Bosset and Liardon, 1984; Brennand et al, 1989; Gallois and Langlois, 1990). Concerning taste, some reports have shown that the water-soluble fraction contains compounds such as peptides, amino acids and salts (Biede and Hammond, 1979; McGugan et al, 1979; Aston and Creamer, 1986) which have a great flavour intens ty. These food constituents are important for their sensory properties. Therefore, crude extracts, partially purified fractions or pure compounds have been subject to sensory evaluation in order to determine their organoleptic impact or their threshold value (Kirimura et al, 1969; Schiffman and Engelhard, 1976; Kato et al, 1989). Most of these sensory experiments were conducted using products dissolved in water or in a water-ethanol mixture for the less polar compounds. This process is open to criticism because the evaluated molecules are not studied in the same environment as in the original food product: interactions with macromolecules such as proteins, lipids or polysaccharides, variations in $\mathrm{pH}$ and ionic strength may affect the headspace concentration of the compounds and thus induce changes in perception. In some cases, simple matrices such as water-ethanol are sufficient because in the original product such as beer, for instance (Abbott et al, 1993), the interactions between the volatile and the non-volatile constituents are weak. However, this is not the case for cheese, where the representativeness of the aroma extract is better when it is incorporated in an oil-water emulsion rather than in water (Etiévant et al, 1994). Therefore, it is necessary to taste them in a medium similar to the food matrix but as bland as pos- sible. This approach has been already carried out for fruit products, for example, tomatoes (Petro-Turza and Teleky-Vamossi, 1989), fruit juice (Casimir and Whitfield, 1978) and particularly for wine (Selfridge and Amerine, 1978; Edwards et al, 1985; Etiévant et al, 1989; Maga, 1990; Martin et al, 1991). It is surprising that for dairy products, to our knowledge, only Roger et al (1988) tried to incorporate 2-phenyl ethanol and its esters in a cheese model to determine their threshold value in cheese. This cheese model was made with a mixture of concentrated skimmed milk retentate, milk fat and flavour compounds, and was subjected to the action of rennet. Our preliminary experiments showed that this cheese exhibited an intense milky flavour due to the crude dairy products used. Several cheese models are described in the literature (Ernstrom et al, 1980; Rubin and Bjerre, 1983a, b; Moran et al, 1989; Stampanoni and Noble, 1991; Tamime et al, 1991; Smit et al, 1995), but the constituents used have an intense flavour and, moreover, these cheese models are subject to draining which leads to the loss of hydrosoluble compounds.

Our target was to develop a cheese model which was easy to prepare, bland and not susceptible to draining. In this paper, we describe the method of preparation of a new cheese model, its chemical, rheological and sensory properties, and some applications for the study of goat cheese flavour.

\section{MATERIALS AND METHODS}

\section{Materials}

Low heat milk powder (MP) was made according to the process described by Schuck et al (1994) and obtained from the Laboratoire de recherches technologie laitiere (LRTL, INRA, Rennes, France). Native calcium phosphocaseinate (NCPP) was prepared by membrane 
microfiltration (Pierre et al, 1992) and obtained from LRTL. Deodorized anhydrous milk fat (MF) was graciously supplied by Corman SA (Goe, Belgium). Sodium chloride, L-glutamic acid, sodium L-glutamate, L-leucine and L-isoleucine were purchased from Merck (Darmstadt, Germany); glucono delta lactone (GDL) was obtained from Fluka (St Quentin Fallavier, France). Food quality amino acids were purchased from Rexim SA (Courbevoie, France). 4-Ethyl octanoic acid was synthesized by Henry, INSA (Lyon, France) (unpublished result) and 4-methyl octanoic acid was obtained from IFF (Dijon, France).

All cheeses mentioned in this paper were bought at local markets, apart from the goat cheese called "Bouton de culotte" bought at the agronomic school of Davayé (Mâcon, France).

\section{Procedure for preparing the cheese model}

All the properties were measured on a cheese model (CM) prepared according to the following procedure (fig 1): six hundred $\mathrm{ml}$ of pure water $(60 \%)$ and $190 \mathrm{~g}$ of MF $(19 \%)$ were prewarmed at $50^{\circ} \mathrm{C}$. First, $30 \mathrm{~g}$ of MP $(3 \%)$ and $2 \mathrm{~g}$ of $\mathrm{NaCl}$ $(0.2 \%)$ were dissolved in warm water. Then, 170 $\mathrm{g}$ NCPP $(17 \%)$ were added in $6 \mathrm{~g}$ aliquots to the solution. Between each addition, the preparation was mixed with a Waring Blender ${ }^{\oplus}$ at 18500 rpm for 3-4 s. After this, $190 \mathrm{~g}$ of warm MF and $8 \mathrm{~g}$ of GDL $(0.8 \%)$ were successively added, mixed in the same manner and held at $33^{\circ} \mathrm{C}$ for $2.5 \mathrm{~h}$. Lastly, $0.15 \mathrm{ml}$ of rennet extract containing $520 \mathrm{mg} \mathrm{H}^{-1}$ of chymosin (Sanofi Bio-Industries, Paris, France), diluted in 9 volumes of water, were added; the mixture was quickly homogenized, held at $33^{\circ} \mathrm{C}$ for $1 \mathrm{~h}$ and stored at $15^{\circ} \mathrm{C}$ until use.

When exogenous single compounds or mixtures were added, the process was modified as follows: NCPP, MP and $\mathrm{NaCl}$ were mixed with the prewarmed water, held overnight at $4^{\circ} \mathrm{C}$, warmed at $50^{\circ} \mathrm{C}$ and mixed with the prewarmed MF. The hydrosoluble compounds were premixed in $20 \%$ of total water containing $1 \%$ of fatty acids sucrose ester (food quality emulsifier SP70, Sisterna, Roosendaal, Netherlands), and added just before the addition of MF. Liposoluble compounds, such as volatile compounds, were premixed with MF, but the emulsifier was always added in order to make comparisons.

\section{Analytical methods}

All the quantitative measurements were repeated 5 times by 3 inexperienced operators. The $\mathrm{pH}$ of the cheese model $(\mathrm{CM})$ was controlled with a $\mathrm{pH}$ meter equipped with a special electrode for hard paste. Dry matter was weighed after heating $5 \mathrm{~g}$ of $\mathrm{CM}$ at $103^{\circ} \mathrm{C}$ for $24 \mathrm{~h}$. Total nitrogen was determined by the Kjeldahl method. After mineralization of $5 \mathrm{~g}$ of $\mathrm{CM}$, distillation and titration were done with a Buschi 342 apparatus coupled with an automatic titration apparatus (Dosimat E535-Titrator E526 METROM).

For free amino-acid quantification, the watersoluble fraction of $\mathrm{CM}$ was extracted. Ten $\mathrm{g}$ of frozen $\mathrm{CM}$ were grated and homogenized in $60 \mathrm{ml}$ of water. The mixture was stirred at $40^{\circ} \mathrm{C}$ for $1 \mathrm{~h}$ and centrifuged at $2000 \mathrm{~g}$ at $4^{\circ} \mathrm{C}$ for $30 \mathrm{~min}$. The supernatant was adjusted to $\mathrm{pH} 4.6$ with $2 \mathrm{~mol}$ $\mathrm{I}^{-1} \mathrm{HCl}$ and centrifuged at $30000 \mathrm{~g}$ at $4^{\circ} \mathrm{C}$ for $30 \mathrm{~min}$. The supernatant was freeze-dried and

Prewarm water and milk fat to $50^{\circ} \mathrm{C}$

$\Downarrow$

Mix milk powder and salt with prewarmed water

$\Downarrow$

Add native calcium phosphocaseinate by $6 \mathrm{~g}$ aliquots and mix 3 s each time

4

Add prewamed milk fat

ป

Add glucono- $\delta$-lactone to adjust the mixture to the required $\mathrm{pH}$

4

Keep $2.5 \mathrm{~h}$ at $33^{\circ} \mathrm{C}$

$\Downarrow$

Add rennet and allow $1 \mathrm{~h}$ at $33^{\circ} \mathrm{C}$

I)

Store below $15^{\circ} \mathrm{C}$ until use $(24 \mathrm{~h})$

Fig 1. Method of production of the cheese model. Méthode de fabrication du fromage modèle. 
the powder obtained was dissolved in $2 \mathrm{ml}$ buffer used for high performance liquid chromatography (HPLC) analysis which was performed according to Dong et al (1985) with an ion exchange column Polyspher AANA $(4.6 \times 25 \mathrm{~cm})$ (Merck) and postcolumn ninhydrin reaction.

For lactose and salt quantification, $20 \mathrm{~g}$ of grated cheese and $50 \mathrm{ml}$ of $12.5 \%$ trichloroacetic acid were homogenized for $5 \mathrm{~min}$, incubated at $70^{\circ} \mathrm{C}$ for $30 \mathrm{~min}$ and centrifuged at $2000 \mathrm{~g}$ at $4^{\circ} \mathrm{C}$. The cream was removed and the supernatant was filtered through a Büchner filter system. The volume of the filtrate was adjusted to $200 \mathrm{ml}$ with pure water. Sodium, potassium and calcium concentrations were analysed with a flame ionisation spectrophotometer (Eppendorf, Hambourg, Germany). After neutralization with $\mathrm{NaOH}$ solution, lactose was quantified by an enzymatic method (Boehringer, Mannheim, Germany).

Total fatty material was extracted according to Folch et al (1957) from a $3 \mathrm{~g}$ cheese sample. The solvent was then removed using a centrifugal concentrator until constant weight.

Total fatty acids were analysed according to the method described by Wolf and CasteraRossignol (1987).

The rheological measurement, made with a digital rheometer INRA-SERT (Cardenas-Caroti et al, 1985), was a uni-axial compression test at constant speed. A cylindrical plug (diameter $200 \mathrm{~mm}$ ) was taken from the cheese model with a cork-borer. Sample height was adjusted to approximately $20 \mathrm{~mm}$ with a two-parallel-wires system. Samples were stored $1 \mathrm{~h}$ before testing at $15^{\circ} \mathrm{C}$, which was the assay temperature. The compression test was performed at a relative deformation of $80 \%$ of the initial height. Force was measured with a $125 \mathrm{~N}$ load cell, as the resistance of the sample to deformation. Stress was calculated as the ratio of force to the initial area of the sample. Cauchy strain, defined as the change of height/initial height, was calculated. Data were represented using a "stress-strain" curve (fig 2). The modulus of deformability, calculated as the slope of the initial linear part of the curve, characterized the elastic properties of the product. Fracture properties were evaluated from the coordinates of the local maximum of the "stress-strain" curve, called fracture strain and fracture stress. Work to fracture was calculated as the area under the curve until the fracture point, and represents the energy needed to deform the product until this fracture point and to break the cheese structure.

\section{Sensory evaluation}

Experiments were conducted in an air-conditioned room $\left(20 \pm 1^{\circ} \mathrm{C}\right)$, under red light in separate booths.

\section{Sensory properties of the cheese model}

The panel consisted of 12 panellists from the staff trained to recognize cheese tastes and flavours. A preliminary step of the study was to choose descriptors. $\mathrm{CM}$ and 2 cheeses with neutral taste (cow Mozzarella and Saint Florentin) were tasted and the most frequently cited descriptors (saltiness, acidity, bitterness, total flavour, milky flavour) were selected. The panellists were asked to rank the 3 samples according to their intensity for each of the 5 descriptors. The mean of ranks was calculated according to Tomassone and Flanzy (1977).

All statistical analyses were performed with the Friedman test followed by a multiple comparison test as described by Tomassone and Flanzy (1977) using the software PSA (OP\&P, Netherlands).

\section{Applications}

\section{Preparations of the samples}

The water-soluble extract of goat cheese was prepared according to Salles et al (1995) without precipitation at $\mathrm{pH} 4.6$ and ultrafiltration steps. Eight $\mathrm{g}$ of freeze-dried powder was dissolved in $0.1 \%$ of SP70 in pure water and incorporated in $100 \mathrm{~g}$ of cheese model.

The volatile fraction was obtained by distillation of the water-soluble fraction under reduced pres-

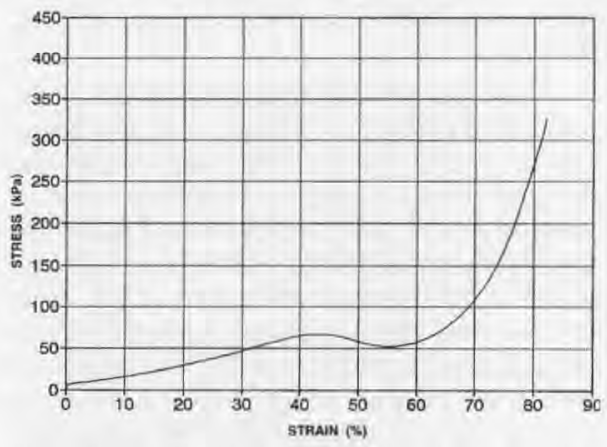

Fig 2. Rheological behaviour of the cheese model. Comportement rhéologique du fromage modèle. 
sure in a modified Forss and Holloway device (Forss and Holloway, 1967). The distillate (1.2 I per $100 \mathrm{~g}$ of cheese) was adjusted at $\mathrm{pH} 2$ with $2 \mathrm{~N}$ $\mathrm{HCl}$, added with $100 \mathrm{~g} \mathrm{I}^{-1}$ of $\mathrm{NaCl}$ and extracted with dichloromethane. The dried organic phase was concentrated to $200 \mu \mathrm{l}$ at $70^{\circ} \mathrm{C}$ with a KudemaDanish apparatus equipped with a Snyder column, and was incorporated directly in $100 \mathrm{~g}$ of cheese model. The residual dichloromethane content in the $\mathrm{CM}$ was quantified by a head-space technique and was found significantly lower $(<0.01$ $\mathrm{ppm}$ ) than the authorized level in food (Official Journal of the European Communities, 1988).

The quantities of pure compounds, determined in the goat cheese (unpublished results), and incorporated in the cheese model were as follows (in mg per $100 \mathrm{~g}$ ):

- Ala (8.1), Arg (3.9), Asp (4.9), Cys (0.25), Cit (0.8), Gln (5.1), Glu (8.3), Gly (1.2), His (1.8), Ile (4.7), Leu (14.2), Lys (5.6), Met (2.9), Phe (8.5), Pro (6.1); Ser (7.0), Thr (4.7), Tyr (5.1), Val (7.1);

- $\mathrm{NaCl}(636), \mathrm{KCl}$ (412), $\mathrm{CaCl}_{2}$ (370);

- unbranched-chain fatty acids: C6:0 (20.7), C8:0 (33.8), C10:0 (8.5);

- branched-chain fatty acids: 4-methyl C8:0 (0.08), 4-ethyl C8:0 (0.009).

\section{Sensory evaluations}

Ten panellists were trained to recognize the basic tastes and the goat aroma. First, the panellists pinched their nostrils and put the sample ( $10 \mathrm{~g})$ on their tongue to evaluate the taste; second, with open nostrils, they evaluated aroma. They were asked to classify each sample on a linear scale according to the intensity of its total taste and then its total aroma. Aroma and taste were described with free vocabulary after the evaluation of both total intensities. The statistical treatment of sensory evaluation data were monitored with SAS statistical software (SAS Institute, 1989) and programs developed in our laboratory. An analysis of variance and a Student-Newman-Keuls test $(P=0.05)$ were conducted for both total taste and aroma intensities.

\section{RESULTS AND DISCUSSION}

\section{Processing of the cheese model}

The nature and proportions of each component were chosen in order to make a CM with all required characteristics: low flavour intensity, no drainage, a cheese-like texture (hard paste) and easy incorporation of flavour compounds.

The preparation and properties of native phosphocaseinate are described by Pierre et al (1992). Its rennet coagulation time is $53 \%$ lower than raw milk; gel development kinetics and final firmness are increased by more than $50 \%$. "Low heat" milk powder prepared by microfiltration of milk followed by drying has also improved rennet coagulation properties (Schuck et al, 1994), due mainly to the low temperature used throughout the drying process, which leads to a low denaturation rate of proteins.

Some milk creams and 1 sample of deodorized MF were tasted to choose the fat. Compared to the creams, which generally have a sweet taste and an intense milky aroma, deodorized MF was found to be tasteless and to have a very low aroma intensity. Moreover, its incorporation in the protein solution was straightforward.

Several types of apparatus were tested for mixing all the components of the CM. Among those tested - Ultraturrax ${ }^{\circledR}$ T25 (IKA-Labortechnick, Staufen, Germany), Kitchenaid ${ }^{\circledR}$ (Kitchenaid Inc, St Joseph, MI, USA) and Waring Blender ${ }^{\circledR}$ (Dynamics Corporation of America, New Hartford, CT, USA) - the latter, used at a low rotation speed, produced a CM with the best appearance: a hard, smooth paste. On the other hand, the Ultraturrax ${ }^{\circledR 1}$ produced a viscous mixture and a $\mathrm{CM}$ with a granular texture while the Kitchenaid ${ }^{\circledR}$ produced a CM with a frothy texture.

The principal problem was to adjust the $\mathrm{pH}$ of the CM. On the one hand, the use of bacteria was prohibited because it led to the production of aroma compounds, while, on the other hand, the addition of acids such as $\mathrm{HCl}$, lactic or citric acids led to local precipitation of caseins before being mixed with the paste and consequently resulted in a $\mathrm{CM}$ of poor quality. The solution was found 
with glucono delta lactone (GDL), which hydrolyzed slowly in the mixture to form gluconic acid. Total acidification was achieved within $2.5 \mathrm{~h}$ after its incorporation. The percentage of GDL used was related to the $\mathrm{pH}$ through the formula:

$$
\% \mathrm{GDL}=1.28 \Delta \mathrm{pH}-0.46
$$

This equation has been determined with quantities of GDL from 0.4 to $1 \%(\mathrm{pH}$ between 6.3 and 5.7), with a coefficient of correlation equal to $99.83(P<0.01, d f=2)$.

Exudation of the $\mathrm{CM}$ was measured by comparing the weight of thirty $50 \mathrm{~g}$ aliquots of $\mathrm{CM}$ after 1 and $2 \mathrm{~d}$ at $14^{\circ} \mathrm{C}$. After $1 \mathrm{~d}$, no drainage was observed and after $2 \mathrm{~d}$, a quantity of water equivalent to only $5 \%$ of the cheese weight was lost $(8.3 \%$ of total water contained in the $\mathrm{CM}$ ). It was thus possible to prepare the cheese model the day before the evaluation test and store it at $4^{\circ} \mathrm{C}$.

\section{Physicochemical analysis}

The physicochemical analyses of the CM are presented in table I. The CM was made by 3 different operators to test the reproducibility of the process. For each operator, 5 analyses were made to test the repeatability of all the physicochemical measures.

We chose to measure the parameters that seemed to us to be the most important concerning the physicochemical characteristics and the flavour of the CM.

For each parameter analysed, the coefficient of variation was generally less than $10 \%$, except 2 values for potassium and calcium, indicating an acceptable repeatability for each operator. Concerning the comparisons between each operator, no significant difference was observed for each analysed parameter. This shows that the $\mathrm{CM}$ can be made easily by inexperienced operators.
All the values obtained for the $\mathrm{CM}$ were compared to mean values itemized by Feinberg et al (1987) for some typical kinds of cheeses (table II).

\section{Dry matter and total $\mathrm{N}$ content}

The dry matter content of the CM was around $40 \%$, which was lower than the value observed for hard-paste cheese (around $60 \%$ ) or soft-paste cheese (close to $50 \%$ ). It was between the values for soft- and freshpaste cheeses. It was found impossible to increase the dry matter content above $40 \%$ without harmful consequences for the final texture of the CM (very viscous paste, bad curdling, grainy texture) and a decreasing of rennet efficiency. A possible explanation could be the difficulty of hydrating the caseins sufficiently (Lorient et al, 1991).

This limitation led to a total $\mathrm{N}$ value lower than those observed for matured cheeses, but close to the values observed for salted cottage cheese or semi-dry goat cheeses (table II).

\section{Fat in dry matter}

The fat in dry matter content of the CM was close to that of a matured cheese (hard- or soft-paste). The fatty acid composition (in $\%$; w/w) was as follows: C10:0, 5.9; C10:1, 0.5; C12:0, 6.8; C14:0, 17.5; C15:0, 1.5; C16:0, 33.1; C18:0, 8.3; C18:1, 17.2; C18:2, $1.3 ; \mathrm{C} 18: 3,0.3$. This composition appeared similar to that of several cheeses (Feinberg et al, 1987).

\section{Sodium}

The sodium content was due mainly to the $\mathrm{NaCl}$ added. The sodium concentration was intentionally kept lower in the CM $(690 \mathrm{mg}$ $\mathrm{kg}^{-1}$ ) than in most of the cheeses (between 2 and $3 \mathrm{~g} \mathrm{~kg}^{-1}$ ) (table II). This will allow incorporation of flavour extracts containing 
salts (particularly water-soluble extracts) without any major consequences on the texture of the CM. Moreover, this low quantity of sodium added in the CM gave a softer paste than that obtained without the addition of $\mathrm{NaCl}$.

\section{Potassium and calcium}

Potassium and calcium were present in concentrations close to those present in matured cheeses. Their origin was mainly MP and NCPP.

Table I. Physicochemical composition of the cheese model.

Composition physicochimique du fromage modèle.

\begin{tabular}{|c|c|c|c|c|}
\hline Operator & $A$ & $B$ & $C$ & F value * \\
\hline \multicolumn{5}{|c|}{ Dry matter (\%) } \\
\hline Mean & 40.2 & 40.3 & 39.5 & 0.8 \\
\hline SD & 0.4 & 0.3 & 0.7 & ns \\
\hline CV (\%) & 1.0 & 0.9 & 1.6 & \\
\hline \multicolumn{5}{|c|}{ Lipids/dry matter (\%) } \\
\hline Mean & 48.0 & 48.3 & 48.2 & 0.4 \\
\hline $\mathrm{SD}$ & 0.6 & 0.4 & 0.7 & ns \\
\hline CV (\%) & 1.2 & 0.8 & 1.5 & \\
\hline \multicolumn{5}{|c|}{ Total $\mathrm{N}\left(\mathrm{g} \mathrm{kg}^{-1}\right)$} \\
\hline Mean & 23.4 & 22.8 & 23.8 & 0.06 \\
\hline SD & 0.6 & 0.6 & 0.5 & ns \\
\hline CV (\%) & 2.4 & 2.6 & 2.1 & \\
\hline \multicolumn{5}{|c|}{ Sodium (mg kg ${ }^{-1}$ ) } \\
\hline Mean & 725.0 & 685.2 & 659.7 & 1.8 \\
\hline SD & 75.5 & 49.9 & 23.9 & ns \\
\hline CV $(\%)$ & 10.4 & 7.3 & 3.6 & \\
\hline \multicolumn{5}{|c|}{ Calcium $\left(\mathrm{mg} \mathrm{kg}^{-1}\right)$} \\
\hline Mean & 5246.4 & 5492.1 & 5582.1 & 2.3 \\
\hline SD & 423.6 & 877.4 & 564.4 & ns \\
\hline CV $(\%)$ & 8.1 & 16.0 & 10.1 & \\
\hline \multicolumn{5}{|c|}{ Potassium ( $\mathrm{mg} \mathrm{kg}^{-1}$ ) } \\
\hline Mean & 707.5 & 735.8 & 717.7 & 0.1 \\
\hline SD & 156.1 & 50.2 & 16.8 & ns \\
\hline $\mathrm{CV}(\%)$ & 22.1 & 6.8 & 2.3 & \\
\hline \multicolumn{5}{|c|}{ Lactose $\left(\mathrm{mg} \mathrm{kg}^{-1}\right)$} \\
\hline Mean & 18904.0 & 18270.0 & 17646.0 & 1.6 \\
\hline SD & 896.0 & 1134.3 & 1282.3 & ns \\
\hline CV (\%) & 4.7 & 6.2 & 7.3 & \\
\hline
\end{tabular}

* Fvalue of operator effect ( $d f=2,12)$. SD: standard deviation; CV: coefficient of variation; ns: not significant.

* valeur $\mathrm{F}$ de l'effet opérateur ( $\mathrm{df}=2,12$ ). $S D=$ écart type ; $C V$ : coefficient de variation ; $n s=$ non significatif. 
Table II. Comparison of the physicochemical composition between the cheese model and some typical cheeses (mean values).

Comparaison de la composition physicochimique entre le fromage modèle et des fromages typiques (valeurs moyennes).

Drymatter Lipid/dry TotalN Sodium Calcium Potassium Lactose

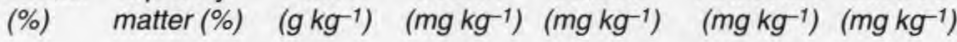

\begin{tabular}{|c|c|c|c|c|c|c|c|}
\hline Cheese model & 40 & 48.2 & 23.3 & 690 & 5440.2 & 720.3 & 18040 \\
\hline \multicolumn{8}{|l|}{ Cow cheese $e^{*}$} \\
\hline Comté & 63.5 & 49.4 & 45.8 & 3150 & 9850 & 1230 & $\star \star \star$ \\
\hline Emmental & 62.3 & 46.5 & 46 & 2210 & 11970 & 1030 & 2000 \\
\hline Cheddar & 64 & 52.3 & 40.8 & 7000 & 7400 & 1000 & \\
\hline Edam & 58.1 & 48.7 & 38.9 & 6540 & 6780 & 670 & ** \\
\hline Camembert & 46.1 & 48.1 & 33.3 & 8020 & 4000 & 1100 & \\
\hline Pont l'Evêque & 49.8 & 48.1 & 33 & 6700 & 5000 & 1370 & \\
\hline Reblochon & 49.3 & 51.9 & & 8700 & 6400 & 2000 & \\
\hline \multicolumn{8}{|c|}{ Cottage cheese (fresh) } \\
\hline not salted & 19.5 & 41 & 12.1 & 290 & 1110 & & \\
\hline salted & 33.2 & 40.3 & 24.1 & 6100 & 840 & & \\
\hline \multicolumn{8}{|l|}{ Goat cheese* } \\
\hline Fresh & 15.4 & 39.6 & 7.4 & 640 & 1080 & & \\
\hline Semi-dry & 51.4 & 54.7 & 26.8 & 5810 & 1030 & & \\
\hline Dry & 69.4 & 56.7 & 43.2 & 7900 & 1900 & & \\
\hline
\end{tabular}

" Feinberg et al, 1987; "** near 0/proche de 0.

\section{Lactose}

The lactose content was quite high in $\mathrm{CM}$ (18 $040 \mathrm{mg} \mathrm{kg}^{-1}$ ), while it was absent from other cheeses due to fermentation by lactic bacteria. This high concentration was due to the addition of MP which contained $53 \mathrm{~g}$ of lactose for $100 \mathrm{~g}$ of dry matter. However, this MP was important in the CM composition because a CM made only with NCPP as source of proteins resulted in a cheese which was too firm.

\section{Free amino acids}

No free amino acids were detected in the $\mathrm{CM}$, as expected, because no proteolysis occurred.

\section{Rheological analysis}

Table III gives the rheological parameters measured on the cheese model sample prepared by the different operators. The variability observed had usual levels. Significant, but low, differences between cheese models $A, B, C$ for the modulus of deformability and the fracture strain were observed while no such difference appeared for chemical parameters. This result suggested a possible, but small, operator effect. It is noticeable that the cheese model had a "stress-strain" curve with a profile similar to hard cheese (Noël, personal communication), but the values of rheological parameters were much lower. The cheese model structure could have a cohesion similar to 
hard cheese but with a softer consistency. This must be confirmed by further investigations, however.

\section{Sensory evaluation}

The results of the sensory evaluation are presented in table IV. The CM was less salty and acid than the 2 cheeses. The differences were significant $(P=5 \%)$. The low saltiness was probably due to the low quantity of $\mathrm{NaCl}$ incorporated in the $\mathrm{CM}$, and the low acidity was probably due to the low quantity of organic acids such as the lactic and propionic acids present.
The bitterness of the CM was similar to that of cow Mozzarella, but lower than that of Saint Florentin $(P=5 \%)$. The absence of proteolysis in the $\mathrm{CM}$, and thus the absence of bitter peptides and free amino acids, could explain the lower bitterness.

The high concentration of lactose in the $\mathrm{CM}$, compared to the very low concentration in typical cheeses (table II), did not seem to influence the taste because sweetness was not mentioned by the panel. Moreover, its mean concentration in CM (53 $\mathrm{mmol} \mathrm{kg}{ }^{-1}$ ) was lower than the detection threshold of lactose in water, which is 72 $\mathrm{mmol} \mathrm{I-1}^{-1}$ (Stahl, 1973).

Table III. Rheological properties of the cheese model.

Propriétés rhéologiques du fromage modèle.

\begin{tabular}{|c|c|c|c|c|}
\hline Operator & $A$ & $B$ & $c$ & $\mathrm{~F}$ value \\
\hline \multicolumn{5}{|c|}{ Modulus of deformability (kPa) } \\
\hline Mean & 83.2 & 97.8 & 97.2 & 4.7 \\
\hline SD & 4.7 & 7.0 & 9.1 & ** \\
\hline CV $(\%)$ & 5.7 & 7.2 & 9.3 & \\
\hline \multicolumn{5}{|c|}{ Fracture stress $(\mathrm{kPa})$} \\
\hline Mean & 70.7 & 71.1 & 63.8 & 3.3 \\
\hline $\mathrm{SD}$ & 7.5 & 3.7 & 2.6 & ns \\
\hline CV (\%) & 5.3 & 5.2 & 4.0 & \\
\hline \multicolumn{5}{|c|}{ Fracture strain (\%) } \\
\hline Mean & 44.5 & 42.7 & 41.8 & 4.3 \\
\hline SD & 1.9 & 0.6 & 1.6 & $\star \star \star$ \\
\hline CV (\%) & 4.3 & 1.4 & 3.9 & \\
\hline \multicolumn{5}{|c|}{ Fracture work (kJ k) } \\
\hline Mean & 12.9 & 14.3 & 13.5 & 1.6 \\
\hline SD & 1.9 & 0.8 & 0.7 & ns \\
\hline CV (\%) & 14.5 & 5.5 & 5.3 & \\
\hline
\end{tabular}

${ }^{*} F$ value of the operator effect $(d f=2,12) ;{ }^{* \star}$ significantly different at $P<0.05$. SD: standard deviation; CV: coefficient of variation; ns: not significant.

*Valeur $\mathrm{F}$ de l'effet opérateur ( $\mathrm{df}=2,12) ;{ }^{\star *}$ différence significative à $\mathrm{P}<0,05 . S D$ : écart type; CV: coefficient de variation; $n s$ : non significatif. 
The CM had the same total flavour intensity as cow Mozzarella, but it was significantly lower than that of Saint Florentin (5\%). No significant difference was found between the 3 products concerning milky flavour.
However, the CM obtained the lowest rank for 8 of 12 panellists. This aroma was linked to the milk powder and the phosphocaseinates and was difficult to eliminate.

Table IV. Comparison of some organoleptic properties between the cheese model and 2 low flavour cheeses.

Comparaison de propriétés organoleptiques entre le fromage modèle et 2 fromages peu aromatiques.

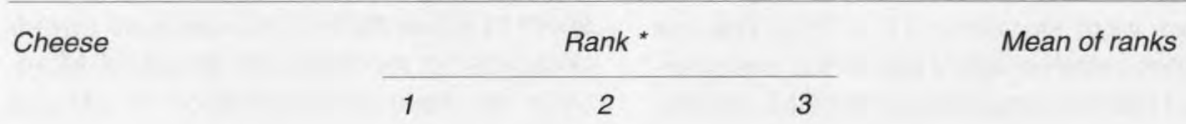

\section{Salty}

Cheese model

Mozzarella

Saint Florentin

$\begin{array}{cccc}10 & 2 & 0 & 1.17 \mathrm{a} \\ 1 & 4 & 7 & 2.50 \mathrm{~b} \\ 1 & 6 & 5 & 2.33 \mathrm{~b}\end{array}$

significant difference at $1 \%=1.19$; at $5 \%=0.96$

Acid

Cheese model

Mozzarella

Saint Florentin

$\begin{array}{llll}7 & 5 & 0 & 1.42 \mathrm{~b} \\ 5 & 7 & 0 & 1.58 \mathrm{~b} \\ 0 & 0 & 12 & 3.0 \mathrm{a}\end{array}$

$\mathrm{FR}=18.16 ; P<0.001$

significant difference at $1 \%=1.19$; at $5 \%=0.96$

Bitter

Cheese model

Mozzarella

Saint Florentin

$\begin{array}{llcl}6 & 4 & 2 & 1.67 \mathrm{a} \\ 6 & 6 & 0 & 1.50 \mathrm{a} \\ 0 & 2 & 10 & 2.83 \mathrm{~b}\end{array}$

$\mathrm{FR}=12.67 ; P<0.01$

significant difference at $1 \%=1.19 ;$ at $5 \%=0.96$

Total flavour

Cheese model

Mozzarella

Saint Florentin

$\begin{array}{llll}5 & 7 & 0 & 1.58 \mathrm{~b} \\ 7 & 5 & 0 & 1.42 \mathrm{~b} \\ 0 & 0 & 12 & 3.0 \mathrm{a}\end{array}$

$\mathrm{FR}=18.16 ; P<0.001$

significant difference at $1 \%=1.19$; at $5 \%=0.96$

Milky flavour

Cheese model

Mozzarella

Saint Florentin

$\begin{array}{llll}8 & 1 & 3 & 1.58 \\ 4 & 4 & 4 & 2.0 \\ 0 & 7 & 5 & 2.42 \\ & \text { FR }=4.17 ; n s & & \end{array}$

The means assigned to the same letter $(a, b)$ are not significantly different at the level of $5 \%$. * Rank 1 : lowest intensity; ns : not significant.

Les moyennes affectées de la même lettre $(a, b)$ ne sont pas significativement différentes au seuil de $5 \%$. " rang 1 : intensité la plus faible; ns : non significatif. 


\section{Examples of incorporation}

\section{General considerations}

The incorporation of substances in the CM, such as pure aroma compounds or aroma extracts, could be made in MF during the process. Concerning more polar compounds, we tried to incorporate pure amino acids, respectively (in $\mathrm{mg} \mathrm{g}^{-1}$ of $\mathrm{CM}$ ): $\mathrm{L}$ leucine (17.8), L-isoleucine (9.7), L-glutamic acid (31) and monosodium L-glutamate (31). These compounds were dissolved in $20 \%$ of the hot water used in the process and then incorporated before the addition of MF. For the incorporation of sodium salts, it was necessary to reduce the equivalent quantity of $\mathrm{NaCl}$ in the process to avoid large changes in the texture of the $\mathrm{CM}$. Moreover, for the same reason, it was necessary to adjust the $\mathrm{pH}$ of the solution of amino acids or hydrosoluble fractions at $6.8 \mathrm{pH}$ of the paste at this step of the procedure) with $\mathrm{NaOH}$ solution before acidification with GDL.

\section{Application to goat cheese}

The results of sensory evaluations are reported in figure 3 for taste and figure 4 for aroma.
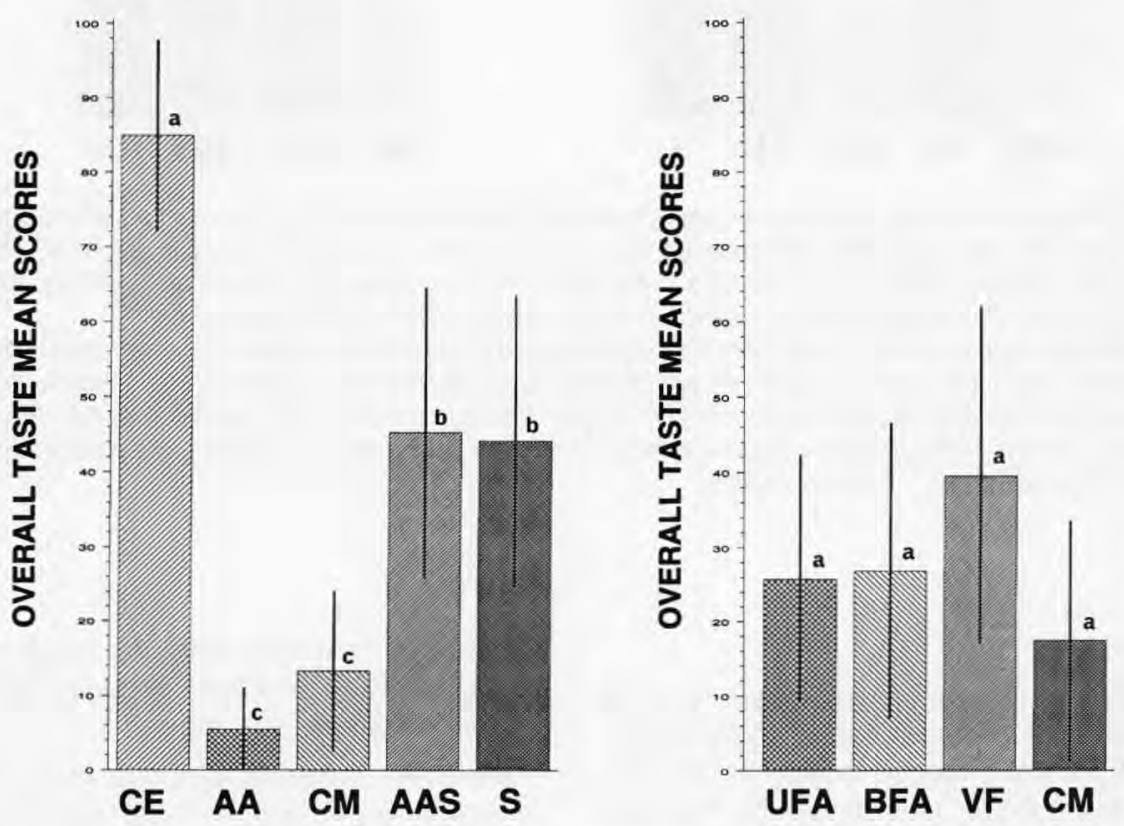

Fig 3. Overall taste mean scores of the reincorporations in the cheese model. The means with the same letter (abc) are not significantly different at the level of $5 \%$. The confidence interval is drawn for each mean. CM: cheese model; CE: crude extract; AA: amino acids; S: salts; AAS: amino acids + salts; UFA: unbranched-chain fatty acids; BFA: branched-chain fatty acids; VF: volatile fraction.

Intensité moyenne de la saveur globale des réincorporations dans le fromage modèle. Les moyennes affectées de la même lettre $(a b c)$ ne sont pas significativement différentes à un seuil de $5 \%$. L'intervalle de confiance est représenté pour chaque moyenne. $C M$ : fromage modèle ; $C E$ : extrait brut ; $A A$ : acides aminés ; $S$ : sels ; AAS : acides aminés + sels ; UFA : acides gras à chaine linéaire ; BFA : acides gras à chaîne ramifiée ; VF : fraction volatile. 

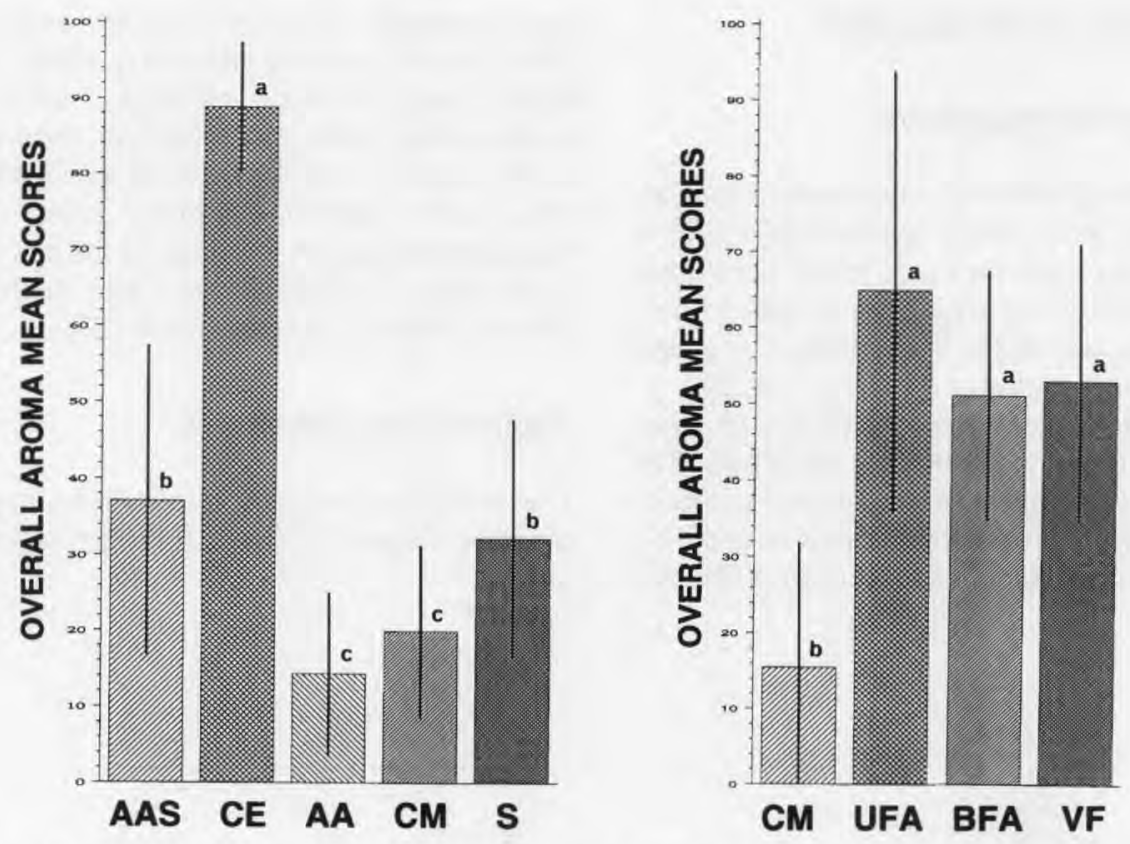

Fig 4. Overall aroma mean scores of the reincorporations in the cheese model. The means with the same letter $(\mathrm{abc})$ are not significantly different at the level of $5 \%$. The confidence interval is drawn for each mean. CM: cheese model; CE: crude extract; AA: amino acids; S: salts; AAS: amino acids + salts; UFA: unbranched-chain fatty acids; BFA: branched-chain fatty acids; VF: volatile fraction.

Intensité moyenne de l'arôme global des réincorporations dans le fromage modèle. Les moyennes affectées de la même lettre $(a b c)$ ne sont pas significativement différentes à un seuil de $5 \%$. L'intervalle de confiance est représenté pour chaque moyenne. $C M$ : fromage modèle ; $C E$ : extrait brut ; $A A$ : acides aminés ; $S$ : sels ; AAS : acides aminés + sels; UFA : acides gras à chaîne linéaire; BFA : acides gras à chaîne ramifiée; VF : fraction volatile.

\section{Taste}

The CM containing the crude hydrosoluble fraction of goat cheese had significantly $(P=$ 0.05 ) the most intense taste. This sample was described as particularly salty. This was probably due to the high quantity of salt present in this extract. Concerning the CM (reference sample), the total taste intensity was low.

The amino acids, branched- or unbranched-chain fatty acid incorporations did not lead to a total taste intensity significantly different compared to the reference sample. For the amino acids, this result can be explained by their low concentration in this kind of cheese (ca. $\mathrm{mg} \mathrm{kg}^{-1}$ ).

Moreover, the addition of salts in the $\mathrm{CM}$ increased significantly the total taste intensity, but under the level obtained by the crude extract. The adjunction of amino acids to the salts had no effect. The difference of taste intensity between the crude extract and salts incorporated in the CM was probably due to other compounds or associations of compounds present in the crude extract. 


\section{Aroma}

As for taste, the crude hydrosoluble fraction had the highest total aroma intensity. The most frequently quoted descriptor was "goat" then "cheese". The CM without incorporation had a low total aroma intensity.

The adjunction of free amino acids did not produce a significant effect. On the other hand, the adjunction of salts increased slightly but significantly the total intensity. This can be explained by a displacement of the residual aroma equilibrium in the $\mathrm{CM}$ because they are noted identically (whey, cardboard).

The incorporation of branched- or unbranched-chain fatty acids, or the volatile fraction leads to an important increase of the total intensity compared to the CM, but the total intensity of these 3 samples are not significantly different.

The samples containing the branchedchain fatty acids was noted "goat" by 8 panellists versus 4 panellists for the unbranched-chain fatty acids (by a total of 10 panellists). This result confirms that the 4-methyl and 4-ethyl octanoic acids are responsible for the typical goat aroma, as previously suggested by $\mathrm{Ha}$ and Lindsay (1991).

\section{CONCLUSION}

The preparation of this cheese model is easy, reproducible and repeatable. The intensity of its flavour was very low; it has a low taste intensity and showed only a slight milky flavour. It is edible if it is made with the usual sanitary precautions used in the dairy industry. The dry matter values and the rheological behaviour study showed that this model is more suitable for work on soft cheeses than on hard varieties.

This kind of cheese model would allow sensory evaluations to determine the impact of some cheese flavour and taste and to obtain more reliable results than if these evaluations were made with water. It will be interesting, for example, to test incorporation of flavour fractions of cheeses obtained by chromatography of the water-soluble fraction (Salles et al, 1995) and to evaluate their effective sensorial impact in cheeses. Threshold measurements of individual flavour compounds found in cheese could also be determined in a more precise way, using this bland cheese-like matrix.

\section{ACKNOWLEDGMENTS}

We greatly acknowledge R Bouhon (SA N Corman, Goe, Belgium) who graciously gave us deodorized anhydrous milk fat, and $P$ Schuck (Laboratoire de recherches de technologie laitiere, INRA, Rennes, France) who graciously gave us native calcium phosphocaseinate and low heat milk powder.

\section{REFERENCES}

Abbott N, Etiévant $P$, Langlois D, Lesschaeve I, Issanchou S (1993) Evaluation of the representativity of the odour of beer extracts prior to analysis by GC-eluate sniffing. J Agric Food Chem 41, 777-780

Adda J, Dumont JP (1974) Les substances responsables de l'arôme des fromages à pate molle. Lait $54,1-21$

Aston JW, Creamer LK (1986) Contribution of the components of the water-soluble fraction to the flavour of Cheddar cheese. NZJ Dairy Sci Technol 21, 229 248

Biede SL, Hammond EG (1979) Swiss cheese flavor. II. Organoleptic analysis. J Dairy Sci 62, 238-248

Bosset JO, Liardon R (1984) The aroma composition of Gruyère cheese. II. The neutral volatile components. Lebensm Wiss Technol 18, 359-362

Brennand CP, Ha JK, Lindsay RC (1989) Aroma properties and thresholds of some branched-chain and other minor volatile fatty acids occurring in milk fat and meat lipids. J Sensory Stud 4, 105-120

Cardenas-Caroti R, Grosclaude G, Nicol G, Maubois JL (1985) Rhéomètre pour l'étude des produits non conformes en corps linéaires. FR Patent 2588379

Casimir DJ, Whitfield FB (1978) Flavour impact values: a new concept for assigning numerical values for 
the potency of individual flavour components and their contribution to the overall flavour profile. Symposium on "Flavours of fruits and fruit juices", Bern, Switzerland

Cuer A, Dauphin G, Kergomard A, Roger S, Dumont JP, Adda J (1979) Flavour properties of some sulphur compounds isolated from cheeses. Lebensm Wiss Technol 12, 258-261

Dong MW, Gant JR, Benson JR (1985) Characterization and performance of a high speed amino acid analysis column. Ann Biotechnol Lab March/April, 34-43

Dumont JP, Roger S, Cerf P, Adda J (1974) Étude des composés neutres volatils présents dans le camembert. Lait 54, 501-516

Edwards TL, Singleton VL, Boulton R (1985) Formation of ethyl esters of tartaric acid during wine aging: chemical and sensory effects. Am J Enol Vitic 36 , 118-124

Ernstrom CA, Sutherland BJ, Jameson GW (1980) Cheese base for processing. A high yield product from whole milk by ultrafiltration. J Dairy Sci 63, 228234

Etiévant P, Issanchou I, Marie S, Ducruet V, Flanzy C (1989) Sensory impact of volatile phenols on red wine aroma: influence of carbonic maceration and time of storage. Sci Aliments 9, 19-33

Etiévant P, Moio L, Guichard E, Langlois D, Lesschaeve I, Schlich P, Chambellant E (1994) Aroma Extract Dilution Analysis (AEDA) and the representativeness of the odour of food extracts. In: Trends in flavour research ( $H$ Maarse, DG Van Der Heij, eds) Elsevier, Amsterdam, 179-190

Feinberg M, Favier JC, Ireland-Ripert J (1987) Répertoire général des aliments. Tome 2. Table de composition des produits laitiers. Tec \& Doc Lavoisier - INRA, Paris, France

Folch J, Lees M, Sloane Stanley GH (1957) Simple method for the isolation and purification of total lipids from animal tissues. J Biol Chem 226, 497-509

Forss DA, Holloway GL (1967) Recovery of volatile com. pounds from butter oil. J Am Oil Chem Soc 44, 572 . 575

Gallois A, Langlois D (1990) New results in the volatile odorous compounds of French cheeses. Lait 70, 89106

Groux M, Moinas M (1974) La flaveur des fromages. II. Étude comparative de la fraction volatile neutre de divers fromages. Lait 54, 44-52

Ha JK, Lindsay RC (1991) Volatile branched-chain fatty acids and phenolic compounds in aged Italian cheese flavors. J Food Sci 56, 1241-1250

Kato H. Rhue MR, Nishimura T (1989) Role of free amino acids and peptides in food taste. In: Flavor chemistry trends and developments (R Teranishi, RG Buttery, F Shahidi, eds) American Chemical Society, Washington, DC, USA, 158-174
Kirimura J, Shimizu A, Kimizuka A, Ninomiya T, Katsuya $N$ (1969) The contribution of peptides and amino acids to the taste of foodstufts. J Agric Food Chem 17, 689-695

Lorient D, Closs B, Courthaudon JL (1991) Connaissances nouvelles sur les propriétés fonctionnelles des protéines du lait et des dérivés. Lait 71, 141 . 151

McGugan WAM, Emmons DB, Larmond E (1979) Influence of volatile and non volatile fractions on intensity of Cheddar cheese flavor. J Dairy Sci 62, 398-403

Maga JA (1990) Sensory and stability properties of added methoxypyrazines to model and authentic wines. In: Developments in food science. Vol 24: Flavors and off-flavors ( $G$ Charalambous, ed) Elsevier, Amsterdam, $61-70$

Martin B, Etiévant P, Le Quéré JL (1991) More clues of the occurrence and flavor impact of Solerone in wine. J Agric Food Chem 39, 1501-1503

Moran JW, Posdal JR, Trecker GW (1989) Manufacture of curd and cheese from a milk retentate. US patent 4820530

Official Journal of the European Communities (1988) Directive du conseil du 13 juin 1988 relative au rapprochement des législations des états membres concernant les solvants d'extraction utilisés dans la fabrication des denrées alimentaires et de leurs ingrédients. (88/344/CEE) L 157 24.6.88, 28-33

Petro-Turza M, Teleky-Vamossi G (1989) Study on taste substances of tomato. Pt 3 : Sensory evaluations. Nahrung 5, 387-394

Pierre A, Fauquant J, Le Graet Y, Piot M, Maubois JL (1992) Préparation de phosphocaséinate natif par microfiltration sur membrane. Lait 72, 461-474

Roger S, Degas C, Gripon JC (1988) Production of phenyl ethyl alcohol and its esters during ripening of traditional Camembert. Food Chem 28, 129-140

Rubin J, Bjerre P (1983a) Process for preparing cheesebase. US patent 4401679

Rubin J, Bjerre P (1983b) A process for preparing cheese-base. UK patent 2101866 A

Salles C, Septier C, Roudot-Algaron F, Guillot A, Etiévant $P$ (1995) Sensory and chemical analysis of water-soluble Comté cheese extracts. J Agric Food Chem $43,1659-1668$

SAS Institute (1989) SAS/STAT user's guide, version 6, 4th edn, vols 1 and 2. SAS Institute Inc, Cary, NC, USA

Schiftman S, Engelhard H (1976) Taste of dipeptides. Physiol Behav 17, 523-535

Schuck P, Piot M, Méjean S, Fauquant J, Brulé G. Maubois JL (1994) Déshydratation des laits enrichis en caséine micellaire par microfiltration ; comparaison des propriétés des poudres obtenues avec celles d'une poudre de lait ultra-propre. Lait 74, 47-63 
Selfridge TB, Amerine MA (1978) Odor thresholds and interactions of ethyl acetate and diacetyl in an artificial wine medium. Am J Enol Vitic 29, 1-6

Smit G, Braber A, Van Spronsen W, Weerkamp AH (1995) Ch-easy model: a cheese-based model to study cheese ripening. Proceedings of Bioflavour 95 Biocatalysts for Flavour Production (P Etiévant and $P$ Schneier, eds) Dijon, France, 14-17 February 1995, 185-190

Stahl WH (1973) Compilation of odor and taste threshold values data. McCormick \& $\mathrm{Co}$, Inc, Baltimore, MD, USA, 75

Stampanoni CR, Noble AC (1991) The influence of fat, acid, and salt on the perception of selected taste and texture attributes of cheese analogs: a scalar study. J Texture Stud 22, 367-380

Tamime AY, Younis MF, Davies G (1991) Production of processed cheese base using Cheddar cheese and cheese base. 2. Production of a cheese base from skim milk powder. Milchwissenschaft 46, 495-499

Tomassone R, Flanzy C (1977) Présentation synthétique de diverses méthodes d'analyse de données fournies par un jury de dégustateurs. Ann Technol Agric 26, 373-418

Wolf RL, Castera-Rossignol A (1987) Mise au point et évaluation d'une méthode d'extraction de la matière grasse de fromage de type emmental. Rev Fr Corps Gras 34, 123-132 